\title{
Environmental law and structural analysis of national ombudsman activities in ensuring rights in penitentiary sphere
}

\author{
Mikhail Olenev ${ }^{1, *}$ \\ ${ }^{1}$ Research Institute of the Federal Penitentiary Service of Russia 15a Narvskaya str., building 1, \\ Moscow, 125130, Russian Federation
}

\begin{abstract}
The article discusses legal basis for organizing the activities of the Ombudsman (Commissioner for Human Rights in Russian Federation) with the penitentiary system in the field of ensuring human rights, makes a structural analysis of the subject of incoming appeals to the Commissioner for Human Rights in Russian Federation, and also highlights the main areas of interaction in the field of ensuring human rights. In connection with the humanization of criminal and criminal-executive policy of Russia, the number of convicts has significantly decreased, material and household and medical support has improved, etc. As of August 1, 2020, 496791 people were kept in the institutions of penitentiary system. (minus 27,137 people compared to 01.01.2020). At the same time, some problems regarding the protection of rights of suspects, accused, and convicted persons in the penal system continue to exist. The search for ways to improve penal system, its social reorientation and humanization determine the appeal to a new type of control over the observance of rights and legitimate interests of both convicts and employees of Federal Penitentiary Service of Russia - the institution of Ombudsman in Russian Federation, since problems related to observance of human rights in this area can accumulate for a long time, however, negative consequences of their non-resolution will further affect society and the state as a whole. The interaction of the Commissioner for Human Rights in Russian Federation and the penal system is manifested primarily in the field of ensuring human rights.
\end{abstract}

\section{Introduction}

The Concept for Development of Penitentiary System in Russian Federation until 2020 (hereinafter - the Concept) has set the goal of humanizing the conditions of detention of persons held in places of deprivation of liberty. This goal remains relevant in the light of development and adoption of a new edition of the same document until 2030. This important goal also follows from the provisions of articles of the Constitution of Russian Federation (Articles 2, 7, 17, 18, etc.) and current laws (for example, Art. 1, Article 8 of the Criminal Executive Code). The problem with observance of human rights in the penal system (hereinafter - PS) is a particular aspect of general problem of ensuring human rights.

${ }^{*}$ Corresponding author: kornei_lam@mail.ru 
The purpose of the study is to establish grounds for organizing interaction of the Commissioner for Human Rights in Russian Federation (hereinafter - the Commissioner) with the penitentiary system, as well as to analyze the main topics of appeals from convicts to the Commissioner. To achieve this goal, it is necessary to fulfill following tasks:

- to analyze the norms of law governing organization of interaction between the Commissioner and the penitentiary system;

- to consider the powers and competence of the Ombudsman in ensuring the rights of convicts;

- to carry out a structural analysis of the subject matter of appeals of convicts to the Ombudsman for Human Rights in Russian Federation to identify problem areas in the field of ensuring human rights in the penitentiary sphere;

- study of statistical information related to the organization of ensuring human rights in penitentiary institutions.

\section{Methods}

Ensuring human rights in the penitentiary sphere with the help of the Commissioner was the subject of research by various authors. So, Yunusov A.A. and Yunusov S.A. define the legal institution of the Commissioner for Human Rights as an additional legal guarantee [1]. Conceptual approaches to organizing the activities of the Commissioner for Human Rights were considered by T. L. Barandova [2] Questions of theoretical substantiation of organization of activities of the Commissioner for Human Rights in ensuring human rights in Russian law at the level of dissertation research were studied by Yu. L. Korabelnikova (Moscow, 2007) [3], Skorobogatova O.V. (Moscow, 2013) [4]. Russian legal science also contains other studies of different years on the stated problem, but, despite this, the problem of ensuring human rights in the penitentiary sphere remains quite relevant and requires an appropriate organization of work of the Commissioner for Human Rights in Russian Federation, since the number of appeals remains high.

The research methodology is built on the basis of an analysis of current legislation, theoretical provisions and practice of organizing the activities of the Commissioner for ensuring human rights in penitentiary institutions. In order to obtain reliable and scientifically grounded results, formal legal, comparative legal, systemic, linguistic, statistical and specific sociological research methods were used in a comprehensive manner.

\section{Results}

One of the ways to ensure human rights in the penitentiary sphere and an additional legal guarantee is the activity of the Commissioner. It acts as an instrument of state recognition, observance and protection of rights and freedoms of citizens and contributes to the achievement of above mentioned goals and objectives enshrined in the concepts. It can be said for sure that by its activities this institution contributes to the creation of a democratic rule-of-law state, the development of legal consciousness of citizens and officials, and also acts as a connecting element between the state and society in the field of human rights protection [5].

The Commissioner acts as a non-judicial form of legal protection and restoration of violated human rights and freedoms [6] in the penal system. A feature of the Ombudsman is almost complete absence of any "power" functions and coercive powers. He/she does not make state-power decisions and his/her activity does not cancel and does not entail a revision of the competence of state bodies. However, the problematic moments that the 
Ombudsman finds when interacting with the penitentiary system help to identify the most priority areas of work to improve the law enforcement mechanism in the penal system.

The main regulatory and legal organization of the Ombudsman's interaction with the penitentiary system in the field of ensuring human rights is the Constitution of Russian Federation, Federal Constitutional Law of February 26, 1997 No. 1-FKZ "On the Commissioner for Human Rights in Russian Federation", partly Federal Law of 19.07. 2018 No. 197-FZ "On service in the penitentiary system of Russian Federation" and "on amendments to the Law of Russian Federation "On institutions and bodies executing criminal sentences in the form of imprisonment"" and the Law of Russian Federation of 21.07.1993 No. 5473-1 "On institutions and bodies executing criminal sentences in the form of imprisonment".

In 2019, the Ombudsman received 38,323 complaints from citizens [7]. Every ninth appeal was received on the implementation of criminal executive legislation (4187 appeals). In this direction, there was an increase in the number of requests compared to the same period last year $+13 \%$ (in 2018 there were 3,695 requests). Thus, the number of complaints regarding detention in temporary detention facilities and pre-trial detention centers has significantly increased from 791 to $1059(+34 \%)$, early release from serving a sentence from 195 to $250(+28 \%)$, there is also a significant increase in the number of complaints use of physical force and special means from 152 to 364 (more than 2 times, + $239 \%)$.

And this despite the fact that there is a gradual decrease in the number of persons held in institutions of the penal system.

Table 1. Indicator.

\begin{tabular}{|l|c|c|c|}
\hline \multicolumn{1}{|c|}{ Indicator } & $\mathbf{2 0 1 9 ( 0 1 . 0 8 )}$ & $\mathbf{2 0 2 0}(\mathbf{0 1 . 0 8})$ & $\begin{array}{c}\text { the same period last } \\
\text { year }\end{array}$ \\
\hline $\begin{array}{l}\text { Number of convicts in } \\
\text { Russia }\end{array}$ & 540657 & 496791 & $-8.2 \%$ \\
\hline $\begin{array}{l}- \text { were held in correctional } \\
\text { facilities }\end{array}$ & 438805 & 389450 & $-11.25 \%$ \\
\hline
\end{tabular}

The rights of the Ombudsman who received the complaint include: accepting the complaint for consideration, explaining to the applicant the means that he/she has the right to use to protect his/her rights and freedoms, transferring the complaint to a state body, local self-government body or an official whose competence is to resolve the complaint on the merits. He/she has the right to freely visit institutions and bodies executing punishment, make inquiries regarding the consideration of a complaint, receive information, documents and materials from state bodies and officials necessary for considering a complaint, receive explanations from officials and civil servants, excluding judges, on issues to be clarified during the consideration of the complaint.

It should be noted that the deprivation of usual way of life, the lack of contact with the outside world, being away from family and friends, the presence of restrictions provided for by the regime of institutions of the penitentiary system, is a serious test for any person. It should be understood that citizens serving a sentence retain all human and civil rights established by the Constitution of Russian Federation and federal legislation, with the exception of those in which they are limited in connection with imprisonment. Employees and those convicted within the penitentiary system should not be subjected to torture, violence, other cruel or degrading treatment. This requirement is enshrined both at the constitutional level (part 2 of Article 21 of the Constitution of Russian Federation) and at the international level (for example, Article 5 of the Universal Declaration of Human Rights). Punishment in modern society is used solely for the purpose of restoring social justice, correcting a convicted person and preventing the commission of new crimes (part 2 
of article 43 of the Criminal Code of Russian Federation). This provision differs from the previous legislation, which considered punishment not only as a measure of coercion, but also as punishment (Part 1 of Article 20 of the Fundamentals of Criminal Legislation of the USSR and the Union Republics of 1958).

Having analyzed the work of the Ombudsman for 2019, following topics can be distinguished from the appeals and complaints of convicts coming:

Complaints about illegal actions of the penal system employees.

The convicts complain about the unjustified and harsh use of physical force and special means against them.

Table 2. Indicator.

\begin{tabular}{|c|c|c|c|}
\hline Indicator & $\mathbf{2 0 1 8}$ & $\mathbf{2 0 1 9}$ & $\begin{array}{c}\text { the same period } \\
\text { last year }\end{array}$ \\
\hline $\begin{array}{c}\text { The number of applications about unjustified and harsh } \\
\text { use of physical force and special means }\end{array}$ & 878 & 951 & $+8.3 \%$ \\
\hline
\end{tabular}

In the group of complaints about unlawful actions of officials of the penal system, most of all there are complaints about the illegal and unjustified use of physical force and special means. Their number has more than doubled compared to 2019.

Table 3. Indicator.

\begin{tabular}{|c|c|c|c|c|}
\hline Indicator & $\mathbf{2 0 1 7}$ & $\mathbf{2 0 1 8}$ & $\mathbf{2 0 1 9}$ & $\begin{array}{c}\text { the same period } \\
\text { last year }\end{array}$ \\
\hline $\begin{array}{c}\text { The number of applications about illegal } \\
\text { and unjustified use of physical force and } \\
\text { special means }\end{array}$ & 114 & 155 & 364 & $+239 \%$ \\
\hline
\end{tabular}

There is a regrettable practice of cruel treatment of prisoners and convicts up to the use of torture. The latter's complaints, reports of public monitoring commissions, the results of visits to places of detention by human rights ombudsmen, as well as appeals to the Ombudsman of public human rights organizations suggest that these cases are not isolated in prisons. These conclusions are confirmed by the results of the supervisory activities of the prosecution authorities. At the request of prosecutors, 471 officers of the Federal Penitentiary Service of Russia were brought to disciplinary responsibility for ill-treatment. 64 criminal cases were initiated on the facts of abuse. All this speaks of the need to strengthen work with the penal system staff in the field of human rights observance.

The European Court of Human Rights (hereinafter - the ECHR) has repeatedly pointed out the inappropriate investigation of the facts of use of violence against prisoners, inhuman or degrading treatment. In 2019, 29 judgments were issued against Russia in violation of Article 3 of the Prohibition of Torture Convention in respect of 39 applicants. The amount of compensation awarded by the ECHR under these judgments amounted to about 700,000 euros.

2. Complaints about the unlawful application of disciplinary measures.

The complaints indicated that the type of punishment was disproportionate to the nature of the offense (violation of internal regulations, including: an unbuttoned button on clothes, an unmade bed, defending one's interests in a conversation with authorities). Complaints of this kind demonstrate a serious upward trend, their increase was almost 9 times. 
Table 4. Indicator.

\begin{tabular}{|c|c|c|c|}
\hline Indicator & $\mathbf{2 0 1 8}$ & $\mathbf{2 0 1 9}$ & the same period last year \\
\hline $\begin{array}{c}\text { The number of applications about illegal } \\
\text { and unjustified use of physical force and } \\
\text { special means }\end{array}$ & 17 & 143 & $+841 \%$ \\
\hline
\end{tabular}

The imposition of a penalty always entails negative consequences for convicts in the form of refusal to grant him/her visits with relatives, on parole from serving a sentence, and transferring to facilitated conditions for serving a sentence. Therefore, the use of penalties can often be one of the means of manipulating the behavior of prisoners for some of the employees of institutions.

3. Appeals on issues of medical support.

Every fifth appeal from places of deprivation of liberty to the Ombudsman contained complaints about the timeliness and quality of medical care in the institutions of the penal system.

Table 5. Indicator.

\begin{tabular}{|c|c|c|c|}
\hline Indicator & $\mathbf{2 0 1 8}$ & $\mathbf{2 0 1 9}$ & the same period last year \\
\hline Number of requests about medical support & 806 & 934 & $+15.8 \%$ \\
\hline
\end{tabular}

In their applications, the applicants expressed disagreement with treatment tactics and prescribed medications, asked for assistance in undergoing examination in civil health care institutions, in obtaining specialized medical care, reported formalism, callousness and indifference to the accused and convicts who need medical assistance. Constructive interaction with the Federal Penitentiary Service of Russia made it possible to positively resolve many of the issues raised in the appeals. Despite the targeted solution of problems in the field of medical care, many questions of this topic remain relevant.

4. Appeals in connection with the inconsistency of conditions of detention in penitentiary institutions with the requirements of penal legislation and international standards.

Table 6. Indicator.

\begin{tabular}{|c|c|c|c|}
\hline Indicator & $\mathbf{2 0 1 8}$ & $\mathbf{2 0 1 9}$ & $\begin{array}{c}\text { the same period } \\
\text { last year }\end{array}$ \\
\hline $\begin{array}{c}\text { Appeals in connection with the inconsistency } \\
\text { of conditions of detention in penitentiary } \\
\text { institutions with the requirements of penal } \\
\text { legislation and international standards }\end{array}$ & 556 & 654 & $+17.6 \%$ \\
\hline
\end{tabular}

Mainly applicants complain about low temperature and overcrowding of cells, low light during the day and constantly burning lights at night, lack of hot water, restrictions on taking a shower, prolonged detention in a cell when it is impossible to go outside during the day, except for an hour's walk, lack of sleeping places.

An important step towards ensuring proper conditions for detention of prisoners and convicts is the Resolution of the Plenum of the Supreme Court of Russian Federation of December 25, 2018 No. 47, which clarified many controversial issues in judicial and law enforcement practice. It lists in maximum detail possible violations of conditions of detention of prisoners and convicts. Deviations from the established containment requirements are regarded as violations of the right to prohibit cruel and inhuman treatment. The Supreme Court of Russian Federation paid special attention to the conditions of detention of prisoners in need of a differentiated approach (pregnant women, nursing mothers, disabled people, minors). 
In 2019, the issue of ensuring proper conditions for the transport of prisoners was the subject of consideration by the European Court of Human Rights (hereinafter - the ECHR), which adopted a pilot judgment in the case "Tomov and Others v. Russia" on inhuman conditions for transporting prisoners in Russia. Six applicants were awarded compensation in the amount of EUR 20,000. The ECHR ruling describes in detail the "torture" conditions for transporting people in prison vans - $1.6 \mathrm{~m}$ high, deaf single "glasses" with an area of about 0.5 square meters and in cells with folding carriage shelves that do not allow prisoners to stand, including long transportation without light, heat, and toilets.

5. Appeals on the issue of transfer for further serving the sentence to another correctional institution located closer to home.

Table 7. Indicator.

\begin{tabular}{|c|c|c|c|}
\hline Indicator & $\mathbf{2 0 1 8}$ & $\mathbf{2 0 1 9}$ & the same period last year \\
\hline $\begin{array}{c}\text { Appeals on the issue of transfer for } \\
\text { further serving a sentence to another } \\
\text { correctional institution }\end{array}$ & 528 & 561 & $+6 \%$ \\
\hline
\end{tabular}

A transfer to a correctional institution, located many thousands of kilometers from the place of residence of relatives, deprives the convict of necessary moral support and does not contribute to his/her correction. Taking into account the need to resolve this problem at the legislative level, in 2020, appropriate changes were made, which will allow convicts to use this right more actively, and, accordingly, it is possible to predict a multiple increase in such appeals to both officials of the penal system and to the Commissioner.

6. Appeals regarding the release of convicts from serving a sentence of imprisonment on parole or due to a serious illness.

In 2019, the number increased to 396 applications (+ 23.4\%). According to the applicants, when deciding this issue, all the circumstances related to their characteristics, the presence of diseases, the time of their sentence served, family circumstances, etc., are not taken into account by the courts. All this also testifies to the need for further humanization and amendments to Article 81 of the Criminal Code of Russian Federation, providing for release from serving a sentence in connection with a serious illness without additional conditions imposed on convicts.

7. Requests for the provision of information and regulatory legal acts.

Many complaints point to the impossibility of obtaining the necessary legal literature, laws in the current edition, samples of procedural documents and other information.

Table 8. Indicator.

\begin{tabular}{|c|c|c|c|}
\hline Indicator & $\mathbf{2 0 1 8}$ & $\mathbf{2 0 1 9}$ & $\begin{array}{c}\text { the same period last } \\
\text { year }\end{array}$ \\
\hline $\begin{array}{c}\text { Requests for the provision of information and } \\
\text { regulatory legal acts }\end{array}$ & 180 & 240 & $+25 \%$ \\
\hline
\end{tabular}

8. Appeals from convicts regarding the social security of prisoners.

Table 9. Indicator.

\begin{tabular}{|c|c|c|c|}
\hline Indicator & $\mathbf{2 0 1 8}$ & $\mathbf{2 0 1 9}$ & $\begin{array}{c}\text { the same period last } \\
\text { year }\end{array}$ \\
\hline $\begin{array}{c}\text { Appeals by convicts regarding the social security } \\
\text { of prisoners }\end{array}$ & 106 & 141 & $+25 \%$ \\
\hline
\end{tabular}

Appeals from convicts are mainly related to assistance in obtaining pensions, social benefits, obtaining identity documents and confirming qualifications, work experience, citizenship, and disability. 
9. Complaints about the procedure and conditions of employment of convicts or about the refusal to engage them in paid work.

Table 10. Indicator.

\begin{tabular}{|c|c|c|c|}
\hline Indicator & $\mathbf{2 0 1 8}$ & $\mathbf{2 0 1 9}$ & $\begin{array}{c}\text { the same period } \\
\text { last year }\end{array}$ \\
\hline $\begin{array}{c}\text { Number of complaints about the procedure and } \\
\text { conditions of employment of convicts or about } \\
\text { the refusal to engage them in paid work }\end{array}$ & 31 & 43 & $+38 \%$ \\
\hline
\end{tabular}

In 2019 , more than $50 \%$ of convicts and $29.4 \%$ of convicts with orders of execution were not employed for various reasons. At the same time, the amount of wages, which de jure should be at least one minimum wage, and de facto, should be much lower than this amount, as well as unpaid work, cause concern.

There are also issues related to the lack of demanded specialties among convicts, which makes it difficult for them to get jobs with acceptable wages after release. Those professions that are taught in correctional institutions are certainly in demand for the institutions of the penitentiary system, but for example, a seamstress, a cutter, a knitter and a number of other specialties for men in life in freedom can hardly be in demand. The state needs to consider the issue of more active training of convicts in additional specialties and their stimulation (including through training outside the walls of penitentiary institutions). These areas of training may not be so in demand in the institution, but they allow convicts to get a job after release and thus benefit society.

In addition to the indicated groups of references, there are other problems in a smaller number. Among them: ensuring the guarantees of rights of women convicts, creating appropriate conditions for detention of persons with disabilities, providing legal assistance to persons in prisons, etc.

And the most alarming thing is that the above mentioned groups of difficulties with ensuring human rights in the penal system are repeated from year to year, which indicates the need to improve the state's criminal executive policy in this area.

The conducted research has shown that a certain experience has been accumulated in organizing the interaction of the Commissioner with the penitentiary system in the field of ensuring human rights. Problems are often multifaceted and repetitive as a result of their unresolved or neglected. However, there is one peculiarity - all these problems concern a special subject - first of all a convict, i.e. a person forcibly limited by the force of the state's punitive apparatus. Obviously, the issue of creating a specialized ombudsman for the rights of persons in places of detention (which largely includes institutions of the penal system) is ripe, which would make it possible to more quickly solve emerging problems in the field of ensuring human rights in such places.

\section{Discussion}

Zapivalov D.A. defines the Ombudsman in organizing interaction with the penitentiary system, as a representative of the state in dealing with convicts, and above all with their low-income categories [8]. According to S.A. Belyakov, it is necessary to devote an independent chapter dedicated to the Ombudsman's control over institutions and bodies executing punishment [9]. According to S.A. Borsuchenko, appeals to the Ombudsman are the main source of information about the violation of rights and legitimate interests of persons in places of detention, as well as one of the main ways of exercising control functions [10].

The Commissioner is called differently in different States. Generally, this institution is called the Ombudsman. From the position of Nikos Vogiatzis, the ombudsman is the main 
instrument of political pressure, with the help of annual reports it is possible to convey to a wide audience the results of the past year and the main problems with ensuring human rights. [11] Galang Asmara believes that the very existence of the ombudsman institution serves as a way to protect citizens' rights from an act of unfair administration, and its presence is mandatory [12]. Nabila FI defines the Ombudsman as an official who helps manage public services and who plays an important role in the delivery of efficient and effective public services [13], protection of human rights, including in the penitentiary sphere [14]. When organizing the work of the Ombudsman, Gottehrer D. highlights such important qualities as independence, impartiality, fairness; reliable process, confidentiality [15].

In our opinion, it is worth agreeing with the opinion of scientists that the Commissioner is a state body and its work is organized according to certain principles. The Ombudsman provides assistance not only to those sentenced to imprisonment, but also to a wide range of persons, including in the event of massive and gross violations of human rights in places of detention. In this regard, it seems advisable to appoint a specialized Commissioner for Human Rights in places of detention, which implies the publication of the corresponding Federal Law "On the Commissioner for Human Rights in Places of Compulsory Detention", which defines his/her competence and legal status. In our opinion, such a human rights defender can function as part of the current structure, which will not require creation of a new apparatus and attraction of additional funds. The creation of a special body designed to protect human rights in places of deprivation of liberty is necessary to overcome the crisis situation in this area. If the Commissioner for Human Rights functions in places of detention, his/her competence should be the issue of introducing commissioners directly in correctional institutions. Such a measure would help to improve the psychological climate in places of isolation, prevent violations by both staff and convicts, which, in turn, would lead to the normalization of the order and conditions for serving a sentence of imprisonment.

\section{Conclusion}

It is hard to disagree that human rights need constant protection. The Ombudsman helps prevent violations of legal human rights. He/she is also entrusted with a high mission he/she helps people to restore and consolidate faith in justice, for which experience, skills and knowledge are required from the ombudsman. But an important condition is also the presence of wisdom in fulfilling such an important national constitutional task - ensuring and protecting human rights. Wisdom allows to solve life problems in a common totality and interaction, since a smart decision in its essence can act as immoral, but a wise one cannot, because wisdom includes both the mind and conscience.

Thus, the analysis of the organization of activities of the Ombudsman in the penitentiary sphere allows us to conclude that the main violations in the field of human rights in the penitentiary system are of a continuing, repeated nature. These appeals relate primarily to the actions of the penal system employees, application of disciplinary measures, issues of medical support, inconsistency of conditions of detention in institutions, transfer for further serving the sentence to another correctional institution located closer to home, release of convicts from serving a sentence of imprisonment conditionally - early or due to a serious illness, order and conditions of employment of convicts, etc.

This is primarily due to the lack of budgetary funds allocated for the needs of penitentiary system, in this regard, there is a decrease in the exactingness and motivation of personnel, as well as poor performance of official powers. Thanks to the activities of the Ombudsman, firstly, the identified problems of ensuring human rights in correctional institutions are revealed and constantly discussed, and, secondly, the position is conveyed 
about the need to correct them at the state level. A great help in solving this problem would be the active use of preventive measures not related to detention, the development of a system of punishments not related to imprisonment, as well as the emergence of a probation service. It should be understood that the PS makes appropriate decisions to improve the situation with human rights, but this process requires time and attention from the state.

\section{References}

1. A.A. Yunusov and S.A. Yunusov, Human: crime and punishment 2, 132-135 (2013)

2. T.L. Barandova, Journal of Social Policy Research 4(10), 505-520 (2012)

3. Yu.L. Korabelnikova, Constitutional and legal foundations of interaction between the Commissioner for Human Rights in Russian Federation and executive authorities in ensuring constitutional rights and freedoms of man and citizen: dissertation ... of a Ph.D of legal sciences (Moscow, 2007)

4. O.V. Skorobogatova, Protection of the rights of persons held in penitentiary institutions by the regional ombudsman for human rights: abstract dis. ... Ph.D. of legal sciences (Moscow, 2013)

5. M.G. Olenev, Law and State: Theory and Practice 11(179), 73-75 (2019)

6. E.A. Yunusov, M.G. Olenev, Law and state: theory and practice 1(181), 258-259 (2020)

7. Report of the Commissioner for Human Rights in Russian Federation for 2019 (M., 2020)

8. D.A. Zapivalov, Bulletin of the Penitentiary System 6, 22-26 (2019)

9. S.A. Belyakov, Criminal-executive law 2, 48-53 (2014)

10. S.A. Borsuchenko, Control over the observance of rights and legitimate interests of those sentenced to imprisonment by the Commissioner for Human Rights in Russian Federation: dis. ... Ph.D. of legal sciences (M., 2004)

11. V. Nikos, Journal of contemporary European research 10(1) (2014)

12. A. Galang, Mediterranean Journal of Social Sciences 8(5) (2017)

13. F.I. Nabila, Jurnal SASI 26(2), 176 - 187 (2020)

14. B. Mirlinda, Academic Journal of Business, Administration, Law and Social Sciences 1(3) (2015)

15. D. Gottehrer, Fundamental Elements of An Effective Ombudsman Institution. In IOI Stockholm conference: Plenary Session II: Developing the Working Methods and Tools of the Ombudsman, http://www 